\title{
Rumenotomy and Caesarean Section in a Cow Affected with Ruminal Impaction and Uterine Torsion
}

\author{
Jobanjit Singh ${ }^{1}$, Jugraj Singh Mahal ${ }^{2 *}$ and Jasmeen Kaur ${ }^{1}$ \\ ${ }^{1}$ Department of Veterinary Surgery and Radiology, Khalsa College of Veterinary and Animal \\ Sciences, Amritsar(143001), Punjab, India \\ ${ }^{2}$ Department of Veterinary Gynecology and Obstetrics, Khalsa College of Veterinary and \\ Animal Sciences, Amritsar (143001), Punjab, India \\ *Corresponding author
}

A B S T R A C T

\begin{tabular}{l} 
K e y w o r d s \\
$\begin{array}{l}\text { Rumen impaction; } \\
\text { Uterine torsion; } \\
\text { Rumenotomy, } \\
\text { Caesarean section; } \\
\text { Pregnant; Cow }\end{array}$ \\
Article Info \\
$\begin{array}{l}\text { Accepted: } \\
12 \text { March } 2020 \\
\text { Available Online: } \\
10 \text { April } 2020\end{array}$ \\
\hline
\end{tabular}

A six year old crossbred HF cow was presented to the Veterinary Clinical Complex, the history of no faecal output from the last 4 days along with anorexia. Animal was full term pregnant. Palpation of the rumen from left paralumbar fossa and per rectal revealed severely impacted rumen. Pervaginal examination revealed post-cervical right sided uterine torsion of approximately $\geq 180$ degree. Based on the findings of clinical examination, the diagnosis of ruminal impaction and post-cervical right side uterine torsion was confirmed. Rumenotomy and caesarean section were performed under local analgesia from the left paralumbar fossa and it was concluded that performing rumenotomy followed by caesarean section was an appropriate method to relieve both the ailments with minimal stress to the animal.

\section{Introduction}

Rumen impaction is among the most common cause of gastrointestinal disorders in ruminants (Ismael et al., 2007 and Bakhiet 2008). The process of fermentation and mixing of contents inside the rumen is hindered by the ingestion of non-metallic foreign bodies such as, plastics, ropes or leather pieces, leading to indigestion
(Radostitis et al., 2000 and Braun et al., 2007). Moreover, the degradation of polythene and other plastic materials does not occur inside the rumen/reticulum and due to churning movements inside the rumen.

They become large tight balls which eventually leads to impaction where animal passes scanty or no faeces (Ramaswamy and Sharma, 2011). Poor quality roughage also 
leads to ruminal impaction especially in animals with depraved appetite (Tyagi and Singh, 2004).

Rumenotomy is advocated for treatment of severe/ long standing cases of ruminal impaction which are unresponsive to conservative treatment (Hartnack et al., 2015). Rumentotomy gives direct access to the rumen, thereby allowing removal of indigested foreign bodies, sharp penetrating objects and foreign bodies lodged in the distal portion of the oesophagus (Ducharme, 1990; Ismael et al., 2007; Patel et al., 2012).
Uterine torsion i.e. the rotation of gravid uterus on its longitudinal axis, has been reported to be one of the major causes of dystocia (Rakuljic-zelov, 2002 and Singh et al., 1992) and among the parturient bovines, it is associated with high rate of dam mortality (Matharu and Prabhakar, 2001). Among many other causes, uterine instability due to dorsolateral attachments of broad ligaments make the bovine population more susceptible to uterine torsion (Sloss and Dufty, 1980). Per-vaginal rotation of foetus, rolling of dam and caesarean section has been advocated for its treatment (Ghuman, 2010) (Fig. 1-3).
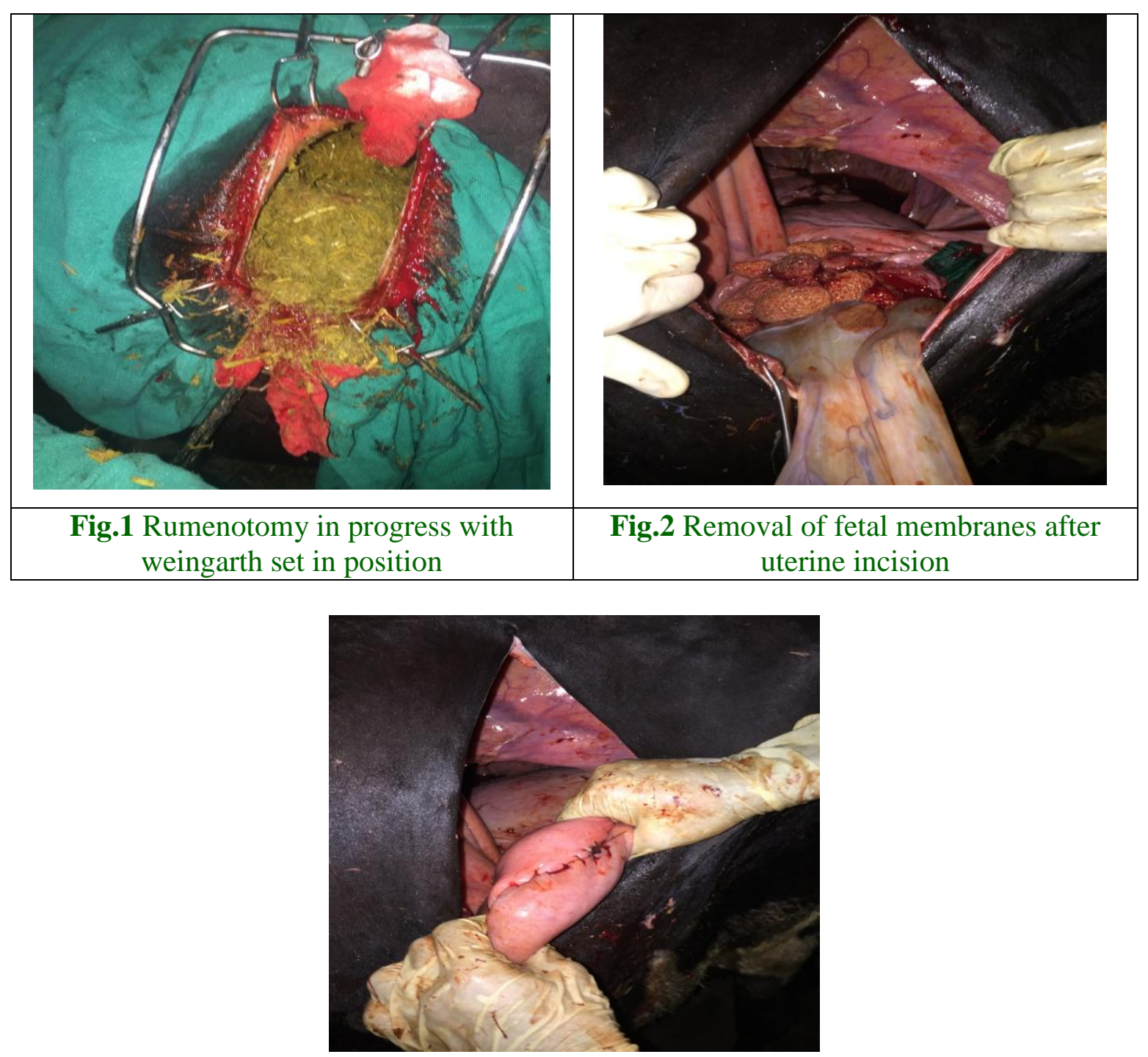

Fig.3 Uterine suturing completed 
In conclusion, we hereby state that the animal was suffering simultaneously with rumen impaction and uterine torsion. Performing rumenotomy followed by caesarean section was an appropriate method to relieve both the ailments with minimal stress to the animal.

\section{References}

Amer, H.A and Hashem, M.A. 2008. Relationship between clinical and biochemical picture of uterine torsion in Egyptian buffaloes. The internet Journal of Veterinary medicine. 4:1.

Bakhiet, A.B. 2008. Studies on the rumen pathology of Sudanese desert sheep in slaughter house. Scientific Research Essays. 3(7): 294-298.

Braun, U, G. Schewizer and Legune, B. 2007.Clinical findings of cattle with traumatic pericarditis.Veterinary Record. 161: 558-563.

Dodia, V.D, N.H. Kelawala, D.N. Sutharand Prajwalita, S. 2014. Haematological and serum biochemical profile of cattle affected with plastic foreign bodies. International journal of scientific and research publications. $4,1-2$.

Ducharme, N.G. 1990. Surgery of the bovine forestomach compartments.Veterinary Clinics North America Food Animal Practice.6, 371397.

Ghuman S.P.S .2010. Uterine torsion in bovines: A review. Indian Journal of Animal Sciences.80(4): 289-305.

Hartnack, A.K, A.J. Niehaus, M. Rousseau, R.L. Pentecost, M.D. Miesner, Anderson D.E. 2015. Indications for and factors relating to outcome after rumenotomy or rumenostomy in cattle: 95 cases. Journal of American Veterinary Medical Association. 247(6): 659664.

Ismael, Z.B, A. Al-Majali and Al-Qudah, K. 2007. Clinical and surgical findings and outcome following rumenotomy in adult dairy cattle affected with recurrent rumen tympany associated with nonmetallic foreign bodies. American Journal of Animal and Veterinary Sciences. 2, 66-71.

Matharu, S.S. and Prabhakar, S. 2001. Clinical observations and success of treatment of uterine torsion in buffaloes. Indian Journal of Animal Reproduction. 22, 45-48.

Murty, K.K, V. Prasad, and Murty, P.R.K. 1999. Clinical observations on uterine torsion in buffaloes. Indian Veterinary Journal 76, 643645.

Patel, R.M, P.B. Patel and Patel, J.B. 2012.Reticular foreign body syndrome in Mehsana buffaloes. Intas Polivet. 13, 42-43

Radostits, O.M, C.C. Gay, D.C. Blood and Hinchcliff, K.W. 2000. Diseases of alimentary tract - II. In: Veterinary Medicine. 9th ed. Book Power Publishers, Philadelphia, U.S.A. pp: 259-346.

Rakuljic-Zelov, S. 2002. Haematological and biochemical profile of cows affected with uterine torsion. Slovenian Veterinary Research. 39(1): 1580- 4003.

Ramaswamy, V and Sharma, H.R. 2011. Plastic bagsthreat to environment and cattle health: a retrospective study from Gondor city of Ethiopia. IIOAP J., 2(1): 7-12.

Reddy, R.Y, T.P. Naidu, S.T. Viroji and Syama, S.N. 2004.Foreign bodies in rumen and reticulum of Punganur cattle. Indian Veterinary Journal.81, 1063.

Singh, V.K., R.D. Sharma, G.S. Dhaliwal, V.K. Gandotra and Prabhakar, S. 1992. Uterine torsion in cows- an analysis of 34 cases. Indian Veterinary Journal. 69, 281-282.

Sloss, V and Dufty, J.H. 1980. Dystocia. Displacement of the gravid uterus. In: Sloss V, Dufty JH, eds. Handbook of Bovine Obstetrics. Baltimore, Maryland: Williams \& Wilkins. Pp. 108-183.

Tyagi, R.P.S and Singh J. 2004. Ruminant Surgery. New Delhi: CBS Publishers and Distributors. Pp. 198-204.

\section{How to cite this article:}

Jobanjit Singh, Jugraj Singh Mahal and Jasmeen Kaur. 2020. Rumenotomy and Caesarean Section in a Cow Affected with Ruminal Impaction and Uterine Torsion. Int.J.Curr.Microbiol.App.Sci. 9(04): 1411-1413. doi: https://doi.org/10.20546/ijcmas.2020.904.167 